магістер-туризмознавець, факультет туризу та міжнародних комунікацій ДВНЗ «Ужгородський національний університет» (Ужгород, Украӥна) һеуһои@і.иа

\title{
ІСТОРІЯ СТВОРЕННЯ ТУРИСТИЧНИХ ПІДПРИЕМСТВ ТА ЇХ СУЧАСНЕ БІЗНЕС-ПЛАНУВАННЯ
}

\begin{abstract}
У статті проаналізовано історію створення та розглянуто сучасні проблеми бізнеспланування нових туристичних підприємств. Авторка дійшла висновку, що історично перші туристичні підприємства з'явилися у другій половині ХІХ ст. Туристичне підприємство є самостійно господарюючим суб 'єктом, що володіє правами юридичної особи, який на основі використання трудовим колективом майна виробляє і реалізує продукцію, виконує роботи, надає послуги у туристичні сфері тощьо.

Розкриття теми стало можливим завдяки використанню загальнонаукових методів пізнання: аналізу, синтезу, системності, узагальнення, конкретності, історизму та діалектичного. Також використано спеијіально наукові методи дослідження: історико-порівняльний, історико-синтетичний, історико-діахронний, емпіричного аналізу тощя.
\end{abstract}

Ключові слова: туризм, туристичне підприємство, туристичний бізнес, туристичні послуги, туристична діяльність.

Jim. 13.

Kateryna KOLODNIUK,

Master of Tourism, Faculty of Tourism and International Communications, Uzhgorod National University (Uzhhorod, Ukraine) heyhou@i.ua

\section{HISTORY OF CREATION OF TOURISM ENTERPRISES AND THEIR MODERN BUSINESS PLANNING}

The article analyzes the history of creation and considers the current problems of business planning of new tourist enterprises. The author came to the conclusion that historically the first tourist enterprises appeared in the second half of the nineteenth century. A tourist enterprise is a self-governing entity that owns the rights of a legal entity, which, on the basis of the use of a labor collective of property, produces and sells products, performs work, renders services in the field of tourism.

In 1872, T. Cook formed a partnership with his son, John Mason Cook, and renamed the travel agency as Thomas Cook \& Son. They acquired business premises on Fleet Street, London. The office also contained a shop which sold essential travel accessories, including guide books, luggage, telescopes and footwear. Thomas saw his venture as both religious and social service; his son provided the commercial expertise that allowed the company to expand.

In accordance with his beliefs, he and his wife also ran a small temperance hotel above the office. Their business model was refined by the introduction of the 'hotel coupon' in 1868. Detachable coupons in a counterfoil book were issued to the traveller. These were valid for either a restaurant meal or an overnight hotel stay provided they were on Cook's list.

Conflicts of interest between father and son were resolved when the son persuaded his father, Thomas Cook, to retire at the end of 1878. He moved back to Leicester and lived quietly until his death.

The firm's growth was consolidated by John Mason Cook and his three sons, especially by its involvement with military transport and postal services for Britain and Egypt during the 1880s, when Cook began organising tours to the Middle East.

In 1880, the Italian government joined Cook's tour company. The Italian economy benefited from additional tourism profits in which Cook programmed and executed as a system. Cook certainly played a key role in not only boosting the Italian economy but also bringing atmosphere and morale of Italian unification. Italians physically felt their country from place to place by traveling.

By 1888, the company had established offices around the world, including three in Australia and one in Auckland, New Zealand and in 1890, the company sold over 31/4 million tickets.

John Mason Cook promoted, and even led, excursions to, for example, the Middle East where he was described as «the second-greatest man in Egypt». However, while arranging for the German Emperor Wilhelm II to visit Palestine in 1898, he contracted dysentery and died the following year. 
Disclosure of the theme became possible through the use of general scientific methods of cognition: analysis, synthesis, system, generalization, concreteness, historicism and dialectical method. The scientific research also uses special scientific methods of research: historical-comparative, historical-synthetic, historical-diachronic, empirical analysis, etc.

Key words: tourism, tourist enterprise, tourist business, tourist services, tourist activity.

Ref. 13.

Екатерина кОЛОДНЮк, магистр-туризмознавеи, факультет туризма и международных коммуникаций ГВУЗ «Ужсгородский национальный университет» (Ужгород, Украина) hеуһоu@i.uа

\title{
ИСТОРИЯ СОЗДАНИЯ ТУРИСТИЧЕСКИХ КОМПАНИЙ И ИХ СОВРЕМЕННОЕ БИЗНЕС-ПЛАНИРОВАНИЕ
}

\begin{abstract}
В статье проанализированы истории создания и рассмотрены современные проблемы бизнеспланирования новых туристических предприятий. Автор пришел к выводу, что первые туристические предприятия появились во второй половине ХІХ в. Туристическое предприятие является самостоятельно хозяйствующчим субъектом, обладающим правами юридического лица, который на основе использования трудовым коллективом имуществом производит и реализует продукцию, выполняет работы, оказывает услуги в туристические сфере.

Раскрытие темы стало возможным благодаря использованию общенаучных методов познания: анализа, синтеза, системности, обобщения, конкретности, историзма и диалектического. В научном исследовании также использованы специально научные методы: историко-сравнительный, историко-синтетический, историко-диахронный, эмпирического анализа и т.п.
\end{abstract}

Ключевые слова: туризм, туристическое предприятие, туристический бизнес, туристические услуги, туристическая деятельность.

Лиm. 13.

Постановка проблеми. Зазначимо, що з розвитком сучасної індустрії туризму провідне місце у цій галузі належить туристичним підприємствам та організаціям. Історія їх становлення і сучасний розвиток спонукають до більш детального вивчення означеної проблематики.

Аналіз досліджень. Дослідження історії та еволюції розвитку туристичних підприємств розглянуті у працях Г. Алейнікової [1], М. Мальської [5], А. Тофанюка [6], В. Федорченка [7], В. Ясинського [11], Е. Левицька [4], В. Цибух [8], І. Школа [9] та ін.

Мета статті - дослідити історію та сучасне бізнес-планування нових туристичних підприємств.

Виклад основного матеріалу. Зазначимо, що туристичні підприємства - це виробничі підприємства різних форм власності, зокрема, державні, приватні, товариства з обмеженою відповідальністю, акціонерні товариства тощо, які виробляють туристичні товари і послуги для громадян. Відповідно, усі туристичні підприємства є частинами туристичної індустрії, яка виробляє товари та послуги. Сучасні туристичні підприємства виконують дві важливі функції:

1. Визначають, які товари і послуги повинні бути продані;

2. Вирішують, у яких місцях мають бути розташовані туристичні фірми [10, 23-27].

Зауважимо, що початок розвитку сучасного туризму та розвитку туристичних підприємств датується 1841 р. Тоді Т. Кук організував першу туристську поїздку для 570 членів товариства тверезості з Лейстера до Лафборо. У той час Т. Кук активно використовував можливості, пов'язані з появою залізниць та зростанням «рухливості» населення. У 1851 р. він організував поїздку 165 тис. осіб на Першу міжнародну промислову виставку до Лондона. Додамо, що у 1855 р. він був організатором першої закордонної поїздки туристів на Всесвітню виставку у Парижі, а 3 наступного року - до інших європейських держав. 31866 р. він почав відправляти на круїзних суднах групи англійських туристів до США, а у 1882 р. відбулася перша навколосвітня подорож Т. Кука. Також він був одним із засновників першого у світі довідника про туристичні підприємства - готелі. Зокрема, у першому виданні було зафіксовано 8000 готельних підприємств.

Саме Т. Кук є засновником першої туристичної компанії «Томас Кук і Син». Слід зазначити, що діяльність очолюваного Т. Куком туристичного підприємства не обмежувалося тільки укла- 
данням договорів із залізничними й пароплавними компаніями, готелями та ресторанами. Компанія займалася маркетингом і менеджментом туризму [13].

У 1866 р. туристичне підприємство організувало перші супроводжені тури по США для британських мандрівників, збираючи пасажирів з кількох пунктів вильоту. Його син, який допомагав у бізнесі, підготував подорож, до якої входили екскурсії місцями боїв громадянської війни. У 1871 р. у Сполучених Штатах з американським бізнесменом було сформовано недовготривале партнерство, назване «Кук, Син і Дженкінс». Перший супроводжуваний кругосвітній тур від'їхав з Лондона у вересні 1872 р. До нього входили подорож через Атлантику, екскурсії по всій Америці, плавання до Японії та сухопутна подорож Китаєм та Індією. Вартість туру, що тривав 222 дні становила приблизно 300 фунтів стерлінгів.

У 1873 р. почалося видання щоквартального (з 1883 р.) Континентального розкладу Кука, яке публікується і у наш час. Зазначимо, що назва компанії була змінена 3 «Томаса Кука і Сина», на «Thomas Cook Group Ltd» y 1974 p. [12].

Мусимо констатувати, що його підприємство стало своєрідним каталізатором: услід за Т. Куком туристичні фірми й агентства почали з'являтися у Франції, Італії, Швейцарії та інших європейських країнах.

Виникнення перших туристських організацій в Україні також припало на цей період. Зазначимо, що історичні процеси формування туристичної галузі в Україні нерозривно пов'язані 3 історією Росії і Австро-Угорщини. Так,

у 1885 р. у Петербурзі було організоване перше у царській Росії «Підприємство для громадських подорожей в усі країни світу» Л. Ліпсона. Воно поклало початок бурхливому розвитку екскурсійної діяльності. Згодом було засновано «Товариство аматорів природознавства» 3 філіями у Петербурзі, Москві та Казані. Значної популярності набув гірський туризм. У 1890 р. в Одесі було створено «Кримський гірський клуб» з філіями в Ялті та Севастополі.

3'явилися перші спеціалізовані журнали:

1. «Екскурсійний вісник»;

2. «Шкільні екскурсії і шкільний музей;

3. «Російський екскурсант»;

Ці видання можна було придбати у Києві, Одесі, Харкові та інших містах України [7, 68-74].

Також зазначимо, що у 1895 р. в Петербурзі організовується Російський «Товариство велосипедистів-туристів», який у 1901 р. був перетворений на «Російське товариство туристів», що мало свої відділення і на території України: Києві, Харкові, Полтаві, Катеринославі, Кам’янці-Подільському, Одесі та деяких інших містах. У перші ж роки своєї діяльності зазначене товариство вступило до Міжнародної ліги туристських товариств. У 1901 р. у Росії створюється «Російське гірське товариство». Воно мало свої відділення у Петербурзі, Москві, Владикавказі, П’ятигорську, Сочі, Алма-Аті. Засновниками товариства були всесвітньо відомі вчені Д. І. Анучин, В. І. Вернадський, І. В. Мушкетов, П. П. Семенов-Тян-Шанський, Б. Ш. Федченко. Товариство ставило перед собою мету - розвиток туризму у Росії, пробудження інтересу до iï пізнання як у Росії, так і за кордоном [7, 68-74].

Зауважимо, що туристична діяльність розвивалася й у Західній Україні, але найкраще - у Галичині. Тут функціонували курортні пыдприємства європейського значення: Трускавець, Моршин, Черче та Немирів [3, 93-97].

Стосовно сучасного розвитку туристичних підприємств, зазначимо, що їх розвиток відбувається на основі бізнес-плану. Бізнес-план - це документ, у якому комплексно обгрунтована стратегія (програма) розвитку всіх сфер діяльності підприємства на основі їі поточного та перспективного планування $[5,103]$.

На наш погляд, бізнес-план повинен передбачати всі етапи діяльності та ефективного розвитку сфери туризму. Зокрема, бізнес-планування управління туристичною діяльністю починається 3 процесу стратегічного планування, тобто з розробки стратегічних планів та програм [6, 153-155].

Сучасні директиви ЄС містять правила ведення підприємницької діяльності у галузі туризму і положення, які встановлюють принципи бухгалтерського обліку на туристичних підприємствах. 
Ці Директиви також зобов'язують державу контролювати туристичну діяльність. Зокрема, цей контроль охоплює такі елементи:

1. Наявність відповідних професійних повноважень для отримання дозволу на здійснення підприємницької діяльності у сфері туризму;

2. Майновий стан, фінансова ситуація, особливо рівень платоспроможності підприємства;

3. Систематичний аналіз туристичних продуктів, що пропонуються.

Стандарти, які містяться у Директивах, мають такі цілі:

1. Надати туристичним підприємствам, зареєстрованим у будь-якій державі Свропейського Союзу, повноваження на здійснення діяльності у всіх державах-членах $\mathrm{CC}$;

2. Надати туристичним підприємствам можливість продавати туристичні послуги без відкриття представництва, підрозділів або філій у конкретних державах [10, 39-43].

У наш час туристичний образ регіону оцінюється за такими критеріями:

а) розвиненість транспортної інфраструктури;

б) гостинність;

в) якість послуг, що надаються, тощо.

Сучасні туристичні фірми в основному займаються поточним та оперативним плануванням [9, 127-134].

Для розробки та здійснення стратегії велике значення має аналіз ринкових чинників. Аналіз показує, що туристичні підприємства, які успішно конкурують у сфері туризму, керуються трьома стратегічними методами, які застосовуються як окремо, так і в поєднанні:

1. Розвиток виробництва туристичного продукту за сформованими напрямками;

2. Формування і продаж послуг за рахунок нових районів туристичного призначення;

3. Впровадження зустрічних сфер туристичної діяльності, у тому числі через створення нових підприємств [6, 153-155; 2, 18-22].

Висновок. Отже, із появою організованого туризму у ХІХ ст. 3'являються перші туристичні підприємства, завдяки яким ця галузь світового господарствам стала масовим явищем. Відзначимо, що сьогодні важливим елементом ефективної діяльності туристичного підприємства $€$ правильне бізнес-планування, яке грунтується на таких бізнес-категоріх - фінансам, людські ресурси, маркетинг, створення туристичного продукту, час тощо.

\section{СПИСОК ВИКОРИСТАНИХ ДЖЕРЕЛ І ЛІТЕРАТУРИ}

1. Алейникова Г. М. Организация и управление турбизнесом / Г. М. Алейникова. - Донецк: ДЦТБ, 2002. - $117 \mathrm{c}$.

2. Бутирська I. В. Основні напрямки розвитку інфраструктури туристського комплексу / I. Бутирська // Муніципальне управління: досвід, проблеми та перспективи: Матеріали Другої міжвузівської науково-практичної конференції студентів та молодих науковців (Чернівці, 12-13 листопада 2004 р.). - Чернівці: Рута, 2004. - С. 18-22.

3. Ключкович Н. Історія та сучасний стан розвитку туристичної інфраструктури в Україні / Н. Ключкович // Східноєвропейський історичний вісник / [головний редактор В. Ільницький]. - Дрогобич: Посвіт, 2017. - Вип. 2. - С. 93-97.

4. Левицкая Э. В. Организация предпринимательства в туризме / Э. В. Левицкая. - Донецк: ДЦТБ, 2000. $-61 \mathrm{c}$.

5. Мальська М. П. Планування туристичної діяльності: підручник / М. П. Мальська, О. Ю. Бордун. К.: Знання, 2010. - 310 c.

6. Тофанюк А. Бізнес-планування в туризмі: тенденції в сучасних умовах / А. Тофанюк // Збірник матеріалів за результатами IV науково-практичної конференції студентів та молодих вчених «Сталий розвиток України: проблеми і перспективи». - Кам'янець-Подільський: Медобори-2006, 2016. - С. 153-155.

7. Федорченко В. К. Історія туризму в Україні: Навчальний посібник / В. К. Федорченко, Т. А. Дьорова. - К.: Вища школа, 2002. - 195 с.

8. Цибух В. І. Стан і перспективи розвитку туризму в Україні / В. Цибух // Туристично-краєзнавчі дослідження. - К., 1999. - 145 с.

9. Школа І. М. Менеджмент туристичної індустрії: Навчальний посібник / За ред. проф. І. М. Школи. Чернівці: ЧТЕІ КНТЕУ, 2003. - 662 c. 
10. Школа I. М. Розвиток туристичного бізнесу регіону: Монографія / За ред. доктора економічних наук, професора Школи I. М. - Чернівці: Книги - XXI, 2007. - 327 с.

11. Ясинський В. В. Бізнес-планування: теорія і практика: навч. посіб. / В. В. Ясинський, О.О.Гайдай. - К.: Каравела, 2006. -232 с.

12. The History of Tourism: Structures on the Path to Modernity. - [Електронний ресурс]. - Режим доступу: http://ieg-ego.eu/en/threads/europe-on-the-road/the-history-of-tourism/

13. Thomas Cook. - [Електронний ресурс]. - Режим доступу: https://en.wikipedia.org/wiki/Thomas Cook.

\section{REFERENCES}

1. Aleynykova H. M. Orhanyzatsyya y upravlenye turbyznesom / H. M. Aleynykova. - Donetsk: DTsTB, 2002. $-117 \mathrm{~s}$.

2. Butyrs'ka I. V. Osnovni napryamky rozvytku infrastruktury turyst·s'koho kompleksu / I. Butyrs'ka // Munitsypal'ne upravlinnya: dosvid, problemy ta perspektyvy: Materialy Druhoyi mizhvuzivs'koyi naukovopraktychnoyi konferentsiyi studentiv ta molodykh naukovtsiv (Chernivtsi, 12-13 lystopada 2004 r.). - Chernivtsi: Ruta, 2004. - S. 18-22.

3. Klyuchkovych N. Istoriya ta suchasnyy stan rozvytku turystychnoyi infrastruktury v Ukrayini / N. Klyuchkovych // Skhidnoyevropeys'kyy istorychnyy visnyk / [holovnyy redaktor V. Il'nyts'kyy]. - Drohobych: Posvit, 2017. - Vyp. 2. - S. 93-97.

4. Levytskaya E. V. Orhanyzatsyya predprynymatel'stva v turyzme / E. V. Levytskaya. - Donetsk: DTsTB, 2000. $-61 \mathrm{~s}$.

5. Mal's'ka M. P. Planuvannya turystychnoyi diyal'nosti: pidruchnyk / M. P. Mal's'ka, O.Yu. Bordun. - K.: Znannya, 2010. $-310 \mathrm{~s}$.

6. Tofanyuk A. Biznes-planuvannya v turyzmi: tendentsiyi v suchasnykh umovakh / A. Tofanyuk // Zbirnyk materialiv za rezul'tatamy IV naukovo-praktychnoyi konferentsiyi studentiv ta molodykh vchenykh «Stalyy rozvytok Ukrayiny: problemy i perspektyvy». - Kamyanets'-Podil's'kyy: Medobory-2006, 2016. - C. 153-155.

7. Fedorchenko V. K. Istoriya turyzmu v Ukrayini: Navchal'nyy posibnyk / V. K. Fedorchenko, T. A. D'orova. - K.: Vyshcha shkola, 2002. - $195 \mathrm{~s}$.

8. Tsybukh V. I. Stan i perspektyvy rozvytku turyzmu v Ukrayini / V. I. Tsybukh // Turystychno-krayeznavchi doslidzhennya. - K., 1999. - $145 \mathrm{~s}$.

9. Shkola I. M. Menedzhment turystychnoyi industriyi: Navchal'nyy posibnyk / Za red. prof. I.M. Shkoly. Chernivtsi: ChTEI KNTEU, 2003. - 662 s.

10. Shkola I. M. Rozvytok turystychnoho biznesu rehionu: Monohrafiya / Za red. doktora ekonomichnykh nauk, profesora Shkoly I. M. - Chernivtsi: Knyhy - XXI, 2007. - 327 s.

11. Yasyns'kyy V. V. Biznes-planuvannya: teoriya i praktyka: navch. posib. / V. V. Yasyns'kyy, O. O. Hayday.K.: Karavela, 2006. $-232 \mathrm{~s}$.

12. The History of Tourism: Structures on the Path to Modernity / [Elektronnyy resurs]. - Rezhym dostupu: http://ieg-ego.eu/en/threads/europe-on-the-road/the-history-of-tourism/

13. Thomas Cook. - [Elektronnyy resurs]. - Rezhym dostupu: https://en.wikipedia.org/wiki/Thomas_Cook. Стаття надійшла до редакиії 14.09.2017 p. 